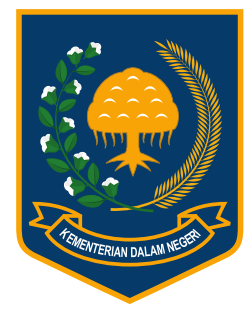

Jurnal Bina Praja 8 (1) (2016): 1-11

Jurnal Bina Praja

e-ISSN: 2503-3360 | p-ISSN: 2085-4323

Accreditation Number

735/AU2/P2MI-LIPI/04/2016

http://jurnal.kemendagri.go.id/index.php/jbp/index

\title{
Strengthening Regional Economic Policy FOR INVESTMENT ATTRACTION: Case in Banten Province
}

\author{
Abdul Halik ${ }^{1, *}$ \\ ${ }^{1}$ Research and Development Agency, Ministry of Home Affairs (BPP Kemendagri) \\ Jl. Kramat Raya No. 132, Senen, Jakarta Pusat
}

Received: 10 February 2016; Accepted: 30 April 2016; Published online: 31 May 2016

\begin{abstract}
The purpose of the study is to analyze the condition of economic potential and economic structure of the region, local investment conditions, as well as to propose a policy in order to strengthen regional economic attraction of investment. The study utilizes qualitative method with descriptive explanation. The result of this study is the attraction of foreign investors and domestic investors to invest in Banten Province is still low, despite the adequately supportive (good enough) economic potential and economic structure in the region. Therefore, it is still necessary to strengthen more appropriate regional economic policies to increase the attraction of investment in Banten province, especially the policy of increasing people's purchasing power (not in the consumptive context).
\end{abstract}

Keywords: economic potential, economic structure, investment.

\section{INTRODUCTION}

Investment activities have provided big contribution in boosting economic growth rate performance, promoting the emergence of local raw material supply industry, process of technology transfer and management, as well as benefits for local investors. The most prominent benefit is the rise of mutual and tied collaboration between foreign investors and local business circle, component business and industry grow rapidly, including various export-oriented businesses.

Investment becomes one of the keywords on every effort to create new economic growth for the expansion of job creation, the growth of income, and the reduction of poverty. Through the development of investement activities, both in the form of domestic and foreign capital accumulation, will be the much needed leverage factor for a country to move its economic machine to go together with a sustaining growth.

Investment development is expected to play a role as a medium for technology transfer and managerial, which eventually will contribute to the growth of production and productivity, as well as economic competitiveness of a country (Sugiarto,
2012). To put it simply, economic growth can be illustrated as a sustainable process of a region's economic condition transformation into a better state.

Nationally, if compared to the previous years, the past 2012 seems to be a golden milestone for the start of Indonesia's investment performance, despite being overshadowed by less profitable global economic condition for the expansion of investment activities development. However, the investment performance of Indonesia in the more recent years show very exciting development.

Data released by the office of Investment Coordinating Board (BKPM) proves that point, which is evident from the investement performance in second quarter or until September 2012, which surpassed Rp 229 trillion or 81,1\% of 2012's target. The investment realization increased about $27 \%$ if compared to the same period in 2011. This gives a positive impact to the additional income (GDP). The $\mathrm{Rp} 222,9$ trillion of Investment performance is the accumulation of capital investment realization, both from domestic capital (PMDN) and foreign direct investment (PMA), in the period of JanuarySeptember 2012, PMDN reached Rp 65,7 trillion and PMA reached Rp 164,2 trillion (Sugiarto, 2012).

\footnotetext{
* Corresponding Author

Phone : +6281386529490

Email : liknph@yahoo.com
} 
One of the encouraging things in Indonesia's structure of investment realization is the start of equal distribution, as reflected on the investment portion outside Java that keeps on increasing. In January-September 2012, investment outside Java reached $\mathrm{Rp} 107,0$ trillion or $46,5 \%$ of the investment total. The number increased if compared to the same period in 2011, which is $\mathrm{Rp} 81,1$ trillion or $44,8 \%$ of the total investment realization. The equal distribution of investment is very crucial to boost economic growth equalization in Indonesia. Furthermore, BKPM aims to gain investement in 2014 amounted to Rp 450 trillion-Rp 470 trillion. This is an opportunity for the region. However, this step needs to be balanced with the totality of local governments to improve the competitiveness of investments in its territory (Investor Daily Indonesia, 2014).

The achievement of the aforementioned investment performance, in reality shows the indicator of the start of various successful efforts in investment climate improvement that have been made by the government to increase investment and provide added value and competitiveness to the national economy. On the other hand, the investment performance shows the increased confidence from business world to Indonesia due to its large population and the increasing number of middle class, which become a major attraction for investment, in addition to the continued improvement in Indonesia's macroeconomy.

But in general, Investment climate in Indonesia is confronted not only by a challenge to gain new investment, but also a challenge to maintain the existing investment. The exit of several multinational companies shows that the investment climate in Indonesia is already on a quite alarming state, although some other parts are still on planning stage. It is predicted that the challenge will be even harder in the future, not only because of external environment that is getting tighter, but also domestic attraction that is still relatively low/small (Bappenas, 2012).

On regional level, local investment is one of the important strengths to accelerate regional development. Normatively, local investment is understood as one of the important strengths to accelerate regional development. Not to mention that among local governments, occurred some kind of awareness - especially after decentralization and regional autonomy implementation - that development acceleration can be possible only if there is a significant investment flow. Decentralization and regional autonomy spirits require local government to cleverly boost development in its region and increase its region's income by digging local potential and attracting investment. Strong perception about the importance of investment demands local government, through the existing bureaucracy machine, to maintain good business climate and not to burden business world and the prospective investor in its own territory.

With the increase of global competition, all countries and regions are competing to attract local andforeigninvestors to investcapitalintheirterritory. With the authority possessed, local government is now as important as central government to increase investment. Local government is demanded to be creative in overcoming the problem of investment climate on its own territory through policy that supports the creation of healthy business climate. Local government is also demanded to compete with other local government to increase local investment attraction. It is due to the motive of business people or investors to move or invest in other region with higher attraction. Investors will choose location that offers bigger profit opportunity with less risk.

Investment becomes the opportunity for local government to maximize the management of economic potential in its region. Besides, investment will play a role to support economic growth of a region. But in general, local government is yet to maximize the management of economic potential that is accompanied by clear and comprehensive agendas internally created by local government (Agussalim, 2011). Formulation of investment policy, perfecting of laws and regulations, composition of investment master-plan, investment information system development, one-roof system or one-stop shop service, partnership development are yet to develope optimally by local government. In concrete, local government is yet to fully experience role reorientation, from traditional role to entrepreneurial role. This among others influence the lack of investment attraction in the region, because conducive entrepreneurship will produce high investment attraction in the region.

In addition, foreign investor attraction is reducingbecause of localautonomy. Decentralization and local autonomy policies in accordance with Law No. 22 of 1999 about Local Government and perfected with Law No. 33 of 2004 is the implementation of one of the reformation demands in 1998. The policies change the governance from centralized to decentralized, which includes among others the transfer of authority from central government to local government (except for foreign politics, defense and security, justice, religion, fiscal and monetary, and other sectors' authority). Through decentralization and autonomy policies, decision making on governance and provision of public service are expected to be simpler and quicker because conducted by the closest local government in accordance with the existing authority. The policies are needed to face the condition development, both domestically and internationally. 
But in reality, decentralization and local autonomy policies are yet to run optimally, including foreign direct investment that instead impacts foreign investor attraction. Many problems faced by foreign investors are related to the authority arrangement of central government and local government in the field of foreign direct investment.

Study results of investment attraction among others are stated by Tri (2009) on Analysis of investement attraction factor and Business World Perception in Batam City, Strategy for Local Investment Development (Wibowo, 2011), Determinant of Investment Attraction (Masri, 2009), and Investment Analysis in Yogyakarta City (Sujatmiko, 2012). These studies focus on local investment, without seeing the relevance with more specific local economy strengthening.

Furthermore, based on the prior study results from Committee of Local Autonomy Implementation Surveillance/KPPOD (2005) about Investment Competitiveness in Districts/Cities in Indonesia of 2005; Business World Perception (Rank of 169 districts and 59 cities in Indonesia: Methodology and Main Finding), there are 5 (five) determinants for local investement attraction, i.e. institutional, security, politics, socio-culture, regional economy, labor, and physical infrastructure. But due to limited time, resource, fund, and to make this study more indepth, then it is limited only on regional economic factor study.

Based on the above study, regional economic factor has the second largest weight (after security, politics, and socio-culture factors) that affects investment competitiveness or attraction of a region, which amounted to $23 \%$. This regional economic factor weight is bigger if compared to the previous year that was only amounted to $17 \%$. Good information about regional economic condition (economic potential and economic structure) will benefit the investors. Investors can allocate their investment on the most efficient regional economic sector. Information needed by investors among others is information about economic power in a region. This is according to Government Regulation No. 45 of 2008 that investors must be provided with conveniences, which among others are the provision of data and information on capital investment opportunity.

The point is, good information about regional economic condition will be able to attract local and foreign investors to enter a region that indirectly will increase people's purchasing power and economic activities, which eventually will also increase OwnSourced Revenue (PAD).

The rationality of the "wherefore" on the importance of the strengthening regional economic policy study for investment attraction is based on the above argument. In this contex, to promote and attract investment to the region, the information of regional economic potential profile that contains proper investment opportunity information for investors is needed. The profile is intended so that investors can be quicker in grasping investment opportunity and making decision for investment. With the existence of the said profile, investors can identify business opportunity in a region. Regional economic sectors are primary sectors (farming, agriculture, and fishery), secondary sectors (production and industry), and also tertiary sectors (trade, servicem hotel, etc). In this concern, needed a strategy for local economic potential development related to the designation of market for the resulted products and also the entrance of investement to the region.

The main concern of this study is the lack of investment attraction in the region. This is shown by the occurrence of less developed realization (project and value) of investment in the region. As for the problem formulation of this study, it is related to the case point, i.e.: (1) How is the condition of economic potential and economic structure?; (2) How is the condition of investment, condition of the number of foreign and domestic investors as well as the realization of project and the value of local investment?; and (3) What policy can be conducted to strengthen regional economy for investment attraction? The purpose of the study: (1) Analyze the condition of economic potential and economic structure; (2) Analyze the condition of the number of foreign and domestic investors as well as the realization of project and the value of local investment and (3) Propose a policy for strengthening regional economy for investment attraction.

To answer the above problem formulation, theoretical or conceptual reference is needed. First, Investment (Capital Investment). Based on economic theory, investment means a purchase (and production) of good not for consumption but for future production (production good) (Sunariyah, 2004). Investment is a component for Gross Domestic Production (GDP) with formulation $\mathrm{GDP}=\mathrm{C}+\mathrm{I}+\mathrm{G}(\mathrm{X}-\mathrm{M})$. So, investment is a form of capital expense for purchasing physical (assets) such as factory, machine, tools, and supplies, which is physical or real investment. In another definition, investment is a commitment upon fund or other resources existing on the present time, with the purpose to bring profit in the future (Tandelilim, 2010).

In Law No. 25 of 2007, investment is all forms of capital investment activities both by domestic or foreign investors to conduct business in the territory of the Republic of Indonesia. Domestic capital investment is the activity of capital investment in the territory of the Republic of Indonesia conducted 
by domestic investors by using domestic capital. Foreign capital investment is the activity of capital investment in the territory of the Republic of Indonesia conducted by foreign investors, both by using entirely foreign capital or in cooperation with domestic investors (Fahmi, 2006).

Furthermore, investors' attraction is the attraction of investors to invest their capital in a country or a region (Charles, 2004). Capital Investors' attraction, both domestic and foreign, is strongly influenced by the will of local government to create friendly business climate. Conducive investment climate happens if together government, private, and public are reaping profit from the existence of investment.

As a result, local government that able to make its region attractive for new investment will get more investment. On the contrary, local government which region is not attractive for investment, not only will it not get new investment, but also the existing investment may exit the region or move to another region. Attractive or not the local investment is, both for foreign companies or domestic investors in every autonomy region, must be different. The quality of policy or regional regulation formulated by local government are affecting investment climate, other than of course the existing resources (Agussalim, 2011).

Second, the Regional Economy. Regional Economy is a measure of system performance in macro regional economy (KPPOD, 2005). Regional economy includes several things, including the main macroeconomic variables (such as total output / GRDP, the price level, and employment), which form the structure of regional economy. The regional economy is used to measure the support of economic potential (availability of natural resources, etc.), as well as the economic structure towards business/ investment. The economy or the regional economy is an open economy. This means that the exportimport activity occurred in the regional economy (Dumairy, 2004).

Economic Potential (Input). Regional development needs to pay attention to the economic potential of the region, which is done by examining the GDRP to see the potential of the base and nonbase in order to optimize the results of development to get a high level of welfare. If a government wants its region to be attractive for investors, the development program should advance from the development of its superior economic potential (Husna, 2012).
The economic potential of the region can basically be defined as any or all resources of the region belong both to natural resources (endowment factors) and the potential of human resources that can provide benefit and can be used as the basic capital for (economic) development of the region (Nuraina, 2010).

Third, the relation between Regional Economy with Investment Attraction. Good information on regional economy conditions (economic potential and economic structure) will benefit investors. Investors can allocate their investment in the most efficient regional economic sector. The information required by investors include information about economic strength in the region. The points is, good information on economic condition of a region will be able to attract domestic and foreign investors to enter a region which indirectly will improve people's purchasing power and economic activity, which in turn will increase Own-sourced Revenue (PAD).

To encourage and attract investment to a region, information of regional economic potential profile that contains information on business opportunities viable for investors is needed. This profile is so that investors can be quicker to capture the investment opportunities and take a decision to invest. With the said profile, investors can identify business opportunities that exist in a region. Sectors of the regional economy is primary sector (farming, agriculture and fisheries), secondary sector (processing and industrial), and tertiary sector (trade, services, hotels and so on). In this regard, there needs to be a development strategy of regional economic potential power relating to the determination of the market for the products produced and also the influx of investment into the region.

Based on the descriptions above, the scope of the regional economy (including economic potential and economic structure) is the performance of the macroeconomic system of the region that includes macroeconomic (such as total output /GRDP, the price level, and employment opportunity), the carrying capacity of economic potential (availability of natural resources, etc.), as well as the structure of economy towards business/investment. Therefore, there are two (2) principal components of the regional economy, namely: (a) economic potential, the physical and non-physical potential of a region/an area such as population/human, natural resources, artificial resources, and social resources. 


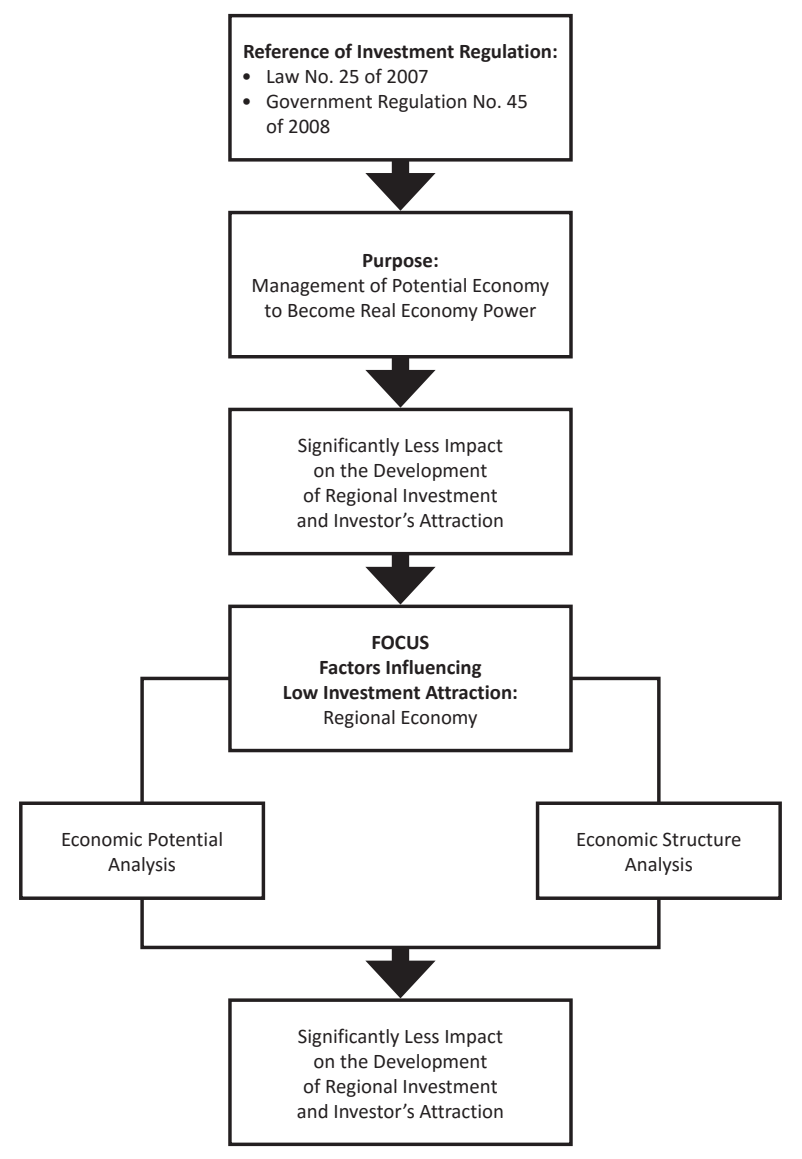

Figure 1. The Flow of Study

Indicators of economic potential are: GDP per capita (purchasing power of people), Regional GDP per capita, or data of the applicable GRDP on the basis of market price and population; Economic growth (average growth), namely the GRDP at constant prices; and construction Cost Index (investment price level), namely the data of construction Cost Index in a region, and (b) Economic Structure is the composition of the role of each sector in the economy both in the field of business and the distribution of sectors into primary, secondary, and tertiary sectors. Indicators of economic structure are: Growth in the primary sector (economic contribution growth of primary sector agriculture), regional primary sector GRDP at constant prices; growth in the secondary sector (production/manufacturing), the regional secondary sector GRDP at constant prices; and growth in the tertiary sector (trade, services, finance, etc.), namely regional tertiary sector GRDP at constant prices.

Strengthening Regional Economic Policy is a regional policyinimprovingregional macroeconomic power that includes macroeconomic (such as total output / GRDP, the price level, and employment opportunity), the carrying capacity of the economic potential (availability of natural resources, etc.), and the economic structure towards investment business activities.

Investment Attraction or Investment is the interest of investors to invest in a country or a region, both domestic investors/domestic and foreign investors (FDI). The indicators are: the number of foreign investors, the number of domestic investor, local investment (project) realization, and local investment (value) realization.

The thinking flow of this study refers to the concept above and schematically illustrated in Figure 1.

\section{METHOD}

This study is a qualitative research (Creswell, 2014). The type of research utilized is descriptive qualitative research, in the form of research with case study method or approach (Yin, 2014) in Banten province, with the consideration that the region has a regional economy that is relatively potential to be developed in order to support investors' attraction to invest in the region. Furthermore, the study was conducted in 1 (one) month, from March 1 to June 30, 2015.

Data collecting technique is conducted in two ways. First, in-depth interviews using an interview guide to parties who are competent in the implementation of regional economic policy and regional investment, which is limited only on Economic Bureau and Regional Investment Coordinating Board (BKPMD) forces. Second, literature review of the document. Third, observation on the Bureau of Economic and BKPMD forces in June 2015.

\section{RESULT AND DISCUSSION}

\section{A. Economic Condition of Banten Province}

In terms of regional economy, GRDP per capita (people's purchasing power) in Banten Province in the period of 2012-2015 has increased, in which GRDP per capita in 2014 rose by 8,81\% from 2013, and in 2015 rose by 8,33\% in 2014. GRDP per capita based on district/cities are all increased in 20122015. But the highest and second-highest GRDP per capita are Cilegon City and Tangerang City, which respectively amounted to $\mathrm{Rp} 97.15$ million and $\mathrm{Rp}$ 36.94 million in 2015. And the lowest and second lowest GRDP per capita are Lebak District and Pandeglang District, respectively only amounted to $\mathrm{Rp} 8.18$ million dan $\mathrm{Rp} 9.01$ million in 2015 . Furthermore, GRDP per capita (people's purchasing power) in Banten Province in 2012-2015 if viewed from absolute value has increased, in which in 2014 rose by $8.93 \%$ from 2013 , and in 2015 rose by $8,00 \%$ from 2014 . If viewed from growth index (GDRP per capita and mid-year population) and GRDP Implicit Cost Index, it is also increased, unless on mid-year population in 2014 that decreased by $0,21 \%$ in 2013 . 
GRDP per capita/people's purchasing power in Banten Province is affected by population growth rate. In addition, the increase in people's purchasing power has not been significant, partly because jobs are lacking. As for the economic growth in Banten Province, it is mostly affected by factors of the workforce. In Banten Province, the workforce is based on the largest field of business, namely trade, agriculture, and industry, so that it can be said that these three business sectors are part of leading sectors. If supported by a large workforce, they will affect economic growth in Banten Privince. In addition, the local government capital spending has an important role in economic growth. The increase of economic activity that will lead to economic growth is inseparable from the role of local government to provide various public services. This facility may be run by the Government through capital expenditure in every district/cities in Banten Province. To further enhance each region's economic growth, it is necessary to supervise and control the use of the fund for development so that it is right on target.

Regional GRDP (economic growth) of Banten province on the basis of constant prices by district/ cities in the period 2012 to 2015 has increased, which in 2014 rose by $6.62 \%$ from 2013, and in 2015 rose by $6.38 \%$ from 2014 . The GRDP in all districts/cities are also increased in the period of 2012-2015. However, the highest, second-highest, and third-highest GRDP are Tangerang City, Tangerang District, and Cilegon City, respectively amounted to $\mathrm{Rp} 33.428 .91$ billion, Rp 20.951.89 billion, and Rp 19.470.57 billion in 2015. And the lowest, second-lowest, and third-lowest GDRP are Serang City, Lebak District and Pandeglang District, respectively only amounted to Rp 3.330.16 billion, Rp 4.607.59 billion, and Rp 4.803.37 billion in 2015 . Furthermore, the Regional GRDP aggegat (economic growth) in Banten province in the period of 20122015 if viewed from absolute value is experiencing growth, which in 2014 rose by $6.39 \%$ from 2013 and in 2015 rose by $6.15 \%$ from 2014 . If viewed from growth index (GRDP per capita) and GRDP implicit Cost Index, it is also increased in the period of 2012-2015.

The factors that influence the growth of the regional economic structure in Banten Province (growth in the primary sector, the secondary sector, and the tertiary sector) are: institutional development, ease of licensing policy, more adequate regional economic infrastructure and potential, and in synergy regional cooperation promotion and cooperation, both in central and regional levels. The factors are: human resources, natural resources, science and technology, culture, and capital Resources.

Construction Cost Index (CCI) in Banten
Province in 2015 is 89,25, far lower than Papua and West Papua, which are respectively 188,70 and 121,01. But CCI of Banten Province is higher than CCI of Central Java Province and Yogyakarta Province, which are respectively 85,38 and 86,52/ But CCI of district/cities in Banten Province in 2013 is varied, in which the lowest CCI is Lebak District, which is 85,65 , meanwhile the highest and secondhighest CCI are South Tangerang City and Tangerang City, which are respectively 103,50 dan 98,40.

Additionally, from regional economic structure side, Banten Province GRDP on the basis of 2000 constant prices according to business field/sector (primary, secondary, and tertiary) is in 2014 rose by $8,38 \%$ from 2013 , and in 2015 rose by $6.15 \%$ from 2014. For primary sectors (farming, husbdandry, forestry, and fishery; as well as mining and excavation) are amounted to Rp 7.344.03 billion in 2015. The sector that contributes the most is food crop, amounted to $\mathrm{Rp} 4.034 .47$ billion, while sector that contributes the least is non oil and gas mining, only amounted to Rp 18.17 million.

For secondary sectors (processing industry; electricity, gas, and clean water; as well as contruction) are amounted to Rp 13.501 .82 billion. The sectors that contribute the most are textile, leather goods, and footwear, amounted to $\mathrm{Rp}$ 4.034.47 billion, while sector that contributes the least is clean water, only amounted to $\mathrm{Rp} 70.81$ million. As for tertiary sectors (trade, hotel, and restaurant; transportation and communication; finance, real estate, and company service; as well as services) are amounted to Rp 37.655.95 billion in 2015. The sectors that contribute the most are wholesale and retail trade, amounted to $\mathrm{Rp}$ 20.087.54 billion, while sector that contributes the least is rail transport, only amounted to Rp 32.09 million.

\section{B. Banten Province Investment Condition}

The illustration of foreign investors' attraction to regional economic condition in Banten Province (towards economic potential and regional economic structure) is that in Pandeglang District, Lebak District, and Serang City, there is no Foreign Direct Investment project in the period of $2012-2015$. This happened partly because the economic condition in those 3 (three) regions (economic potential and regional economic structure) is considered by foreign investors to be less supportive and less profitable for those foreign investors to invest their capital. As for the illustration of domestic investors' attraction to regional economic condition in Banten Province (towards economic potential and regional economic structure) is that in Pandeglang District, Lebak District, Serang City, and South Tangerang Selatan, there is no Domestic Investment project in the period of $2012-2015$. This happened partly 
because the economic condition in those 5 (five) regions (economic potential and regional economic structure) is considered by domestic investors to be less supportive and less profitable for those domestic investors to invest their capital in those 5 (five) regions.

The influence of regional economic condition in Banten Province (Economic Potential and Regional Economic Structure) towards investors' attraction is, if regional economic potential (people's purchasing power and economic growth) cannot be developed by local government, and also regional economic structure (primary, secondary, and tertiary) is not supportive, so investors will not be interested to invest their capital in Banten Province.

Moreover, the relation between economic condition and investment in Banten Province. If viewed from economic potential of Banten Province in the aspect of GRDP per capita or people's purchasing power, foreign or domestic investors are presumably interested to invest their capital in Cilegon City and Tangerang City because these two cities have high GRDP per capita if compared to 6 district/cities in Banten Province, respectively amounted to $\mathrm{Rp} 97.15$ million and Rp 36.94 million in 2015. However, in reality only Tangerang City that has 20 FDI projects, while Cilegon City only has 4 FDI projects. On the contrary, Tangerang District and South Tangerang City, which GRDP per capita are not too high, have respectively 26 and 17 FDI projects. Serang District has 5 FDI projects, while Pandeglang District, Lebak District, and Serang City do not have any FDI project. Therefore, FDI expansion in Banten Provence is necessary, especially in district/cities with minimum FDI project. Furthermore, if viewed from Domestic Investment, Cilegon City and Tangerang City still have high GRDP per capita, but only Tangerang City that has 2 Domestic Investment projects, while Cilegon City has no Domestic Investment projects. Meanwhile, Tangerang District and Serang District, which GRDP per capita are not too high, have respectively 10 and 6 Domestic Investment projects. Padeglang District, Lebak District, Serang City, and South Tangerang City do not have any Domestic Investment project. Therefore, FDI and Domestic Investment expansion is necessary on Banten Province, especially in district/cities with minimum FDI and Domestic Investment projects.

If viewed from economic potential of Banten Province in the sector of regional GRDP or economic growth, foreign investors and domestic investors should be more interested to invest their capital in Tangerang City, Tangerang District, and Cilegon City because these three regions have high GRDP if compared to five other areas, which respectively are Rp. 33.428.91 billion, Rp. 20.951.89 billion, and Rp. 19.470 .57 billion in 2015 . However, in reality only
Tangerang City and Tangerang District that have relatively many FDI projects, with respectively 20 and 26 FDI projects, while Cilegon City only has 4 FDI projects. Furthermore, if viewed from the side of domestic investment, Tangerang District has 10 domestic investment projects, Tangerang City only has 2 domestic investment projects, while Cilegon city does not have any domestic investment project. Such condition certainly will require regional GRDP development efforts to increase regional GRDP or economic growth in Banten Province in order to make both foreign investors and domestic investors interested to invest in the province.

If viewed from GRDP of Banten Province on the basis of constant prices of 2000 according business field/sector (primary, secondary, and tertiary), the contribution of the primary sector (Rp 7.344.03 billion in 2015) does not affect the attraction of foreign investors and domestic investors to invest in those sector, because there is no FDI projects and domestic investment projects in the primary sector. For the contribution of the secondary sector (Rp 54.999 .64 billion in 2015), only the textile, leather goods and footwear sectors that are considerably influencing the attraction of foreign investors (there are 14 FDI projects in this sector). Meanwhile the attraction of foreign investors' to the contribution of the tertiary sector ( $\mathrm{Rp} 37.655 .95$ billion in 2015) is focused on trade, hotels and restaurants, as well as services (respectively there are 29 and 8 FDI projects in this sector). Furthermore, the attraction of domestic investors to the contribution of the secondary sector is very low (the highest is only 3 domestic investment projects, even there are some sectors that do not have domestic investment projects). The attraction of domestic investors to the tertiary sector is only focused on finance, real estate, and company services (there are 8 domestic investment projects in this sector).

If viewed from the Construction Cost Index (CCI), CCI of Banten Province in 2015 is amounted to only 89.25. This CCI is much lower than Papua and West Papua, which are respectively 188.70 and 121.01. The CCI of district/cities in Banten Province in 2015 is varied, in which the lowest CCI is in Lebak District, which is 85.65, while the highest and second highest are South Tangerang City and Tangerang City, respectively 103,50 and 98.40. Furthermore, although the CCI in Banten province is relatively small, but the impact on the attraction of foreign investors and domestic investors does not occur in all districts/ cities in Banten Province. It is because only Tangerang District, Tangerang City, South Tangerang City, and Serang City that have more FDI projects or domestic investment projects than other 4 (four) districts/cities in the province of Banten. 


\section{Strengthening Regional Economic Policy in the Context of Investment Attraction in Banten}

Related with the conditions above, there are at least four (4) basic components that need to be strengthened from strengthening regional economic policy of Banten Province, namely GRDP per capita (people's purchasing power), Regional GRDP (economic growth), GRDP of every business field/ sector (primary, secondary, and tertiary), and CCI (Construction Cost Index). Thus, the increase in the attraction of FDI and domestic investment investors in making their investment in Banten Province, in relation with regional economic condition, can be achieved through repairing efforts towards those the four components.

Based on the author's interview with informants in the field, revealed the policies that need to be done (as proposed by informants). First, the increase in GRDP per capita (purchasing power of people). Banten Provincial Government needs to continue encouraging an increase in GRDP per capita of districts/cities in the region, particularly for districts/cities with low/small GRDP per capita, such as Lebak District and Pandeglang District. The increase of people's purchasing power has not been very significant in the province. Therefore, the local government needs to improve the purchasing power to sustain domestic consumption that supports economic growth. So far domestic consumption is still considered as the backbone of the national economy, thus local government needs to improve people's purchasing power to support domestic consumption.

Second, the increase of regional GRDP (local economic growth). Banten Provincial Government needs to continue encouraging an increase of regional GRDP of districts/cities in the region, particularly for districts/cities with low/small regional GRDP, such as Serang City, Lebak District, and Pandeglang District.

Third, the increase of GRDP in every business field/sector (primary sector, secondary sector, and tertiary sector). Banten Provincial Government should continue to make effort in increasing GRDP of all districts/cities in Banten Province in every business field/sector, especially in the sectors with low/ small contribution if compared to other sectors, such as in the primary sector, which is non oil and gas mining (only Rp 18.17 million), in the secondary sector, which is clean water (only $\mathrm{Rp}$ 70.81 million), and in the tertiary sector, which is rail transport (only Rp 32.09 million).

Fourth, Maintaining CCI (Construction Cost Index) that is relatively small. Banten Provincial Goverment as much as possible control the CCI (Construction Cost Index) in its territory, or at least can maintain a relatively low/small current CCI if compared to CCI of other provinces in Indonesia. CCI of Banten Province is just 89.25. This CCI is much lower if compared to CCI in Papua and West Papua, which are respectively 188.70 and 121.01.

In addition, based on the author's interview with informants in the field, expressed the need for ways that can be done by Banten Provincial government in implementing the policy of increasing GRDP per capita, regional GRDP, as well as GRDP of every business field/ sector, as described below.

Controlling the rate of population growth in the province of Banten. Total population at mid-year in Banten Province in 2014 is 102.50 and increased in 2015 to 102.75. GRDP per capita/purchasing power of people is affected by population growth. So, to further increase the per capita income, the rate of economic growth should be increased, and in return the rate of population growth needs to be controlled. Basically, the rapid population growth rate will affect the economic development, especially the development of regional revenue. The higher the population growth rate, the lower the regional income, conversely, the lower the rate of population growth, the higher the regional income, assuming the economic growth rate is fixed. Therefore, the control the population in order to increase regional revenue should be really considered by both the local government and the people.

The increase of regional investment in Banten Province. Just like the previously described data of domestic and foreign investment, this region's FDI and Domestic Investment is not yet maximized. To improve the investment climate, Regional Investment Coordinating Board (BPMPD) needs to have main agendas related to the improving of services and repairing of infrastructure, such as: preparing the institutional, human resources, management, providing a map of local investment potential, identifying featured investment projects, forming coordination team for investment climate strengthening in the region, optimizing the coordination team of local Capital Investment Activity Report (LKPM), encouraging the provision of incentives and ease of investment in the region, encouraging the development of industrial zones and selected strategic areas, and encouraging increased investment climate in the region. Another agenda can also be done through one-stop investment service, participation in investment expo, comparation study on investment service, streamlining promotion, service, and guidance of the implementation of the investment, and so on.

Cooperation and integration of the districts/ cities that are part of districts/cities in Banten Province. Each district/city has specialized commodity according to its featured sector/ subsector. With the specialization of commodities that is based on its sector/sub-sector, of course, can 
lead to sectoral activities in each district/city to be diverse. The diversity of sectoral activities of each district/ city will later encourage the creation of economic activities between districts/cities. Thus creating linkages and inter-district/city mutual relation, so that the relation will accelerate economic growth in its respective district/city in the region.

Creating job opportunity as much as possible in Banten Province. The increased purchasing power of people is yet to be significant in the province, partly because job opportunity is lacking. One of the efforts that can be done by local governments to increase the purchasing power of people is by creating job opportunity as much as possible. However, local government is advised to give priority to job opportunity creation in formal sector. This is important to be done by local government. There is no better permanent way besides creating job oppotunity, but not in informal sector. In Banten Province, in 2015, an increase in the number of economically active population is significant, the number of workforce reached up to $5,475,876$ people, an increase of 77,232 people if compared to the condition in $2014(5,398,644$ people). Thus, a somewhat large workforce must be balanced with sufficient job opportunity. The largest business fields for these workforce are trade, agriculture, and industry, so that it can be said that these three business fields are included on leading sectors. If supported by a large workforce, they will affect economic growth in the region. Local government needs to give more attention to the workforce, especially in the aspect of increasing productivity, quality, and social security, which later expected the welfare of workers can be met so that the productivity increases and economic growth in the region is growing.

Raising wages in Banten Province. Minimum Wage of Banten Province is Rp 1.042 million in 2014 and in 2015 is Rp 1.17 million (raised by 12.28\%). The raise in the minimum wage is still considered by workers to be small or not meeting their needs. Related to the effort of local government to increase people's purchasing power by raising the wage on a regular basis, it is very difficult because the "moving space" of local government is not too big to do it. However, the raise in wages can be done in a small percentage but periodically. It is because if the percentage is big, it will be rejected by employers. Employers will be 'screaming' because periviously there was a quite big raise of wages ."

Prioritizing local budget (APBD) allocation to sectors that have absorptive capacity of large workforce in Banten Province. The sectors that are mostly able to absorb a large workforce are particularly agriculture and labor-intensive industries. In these sectors, budget allocation is enlarged, and with a solid program, it is expected that this can be good for the welfare of the lower middle class people. In Banten, the structure of local budget of 2015 has increased by 7.74 percent or Rp 410 billion if compared to the 2014 revised budget of Rp 5.66 trillion. The budget is ideally allocated in sectors that have absorptive capacity of large workforce.

The use of capital expenditure allocation is directed more on infrastructure development in Banten Province. It is intended to encourage local economic growth in a sustainable manner. To maintain the momentum of regional economic growth by maintaining domestic consumption is difficult to do in the middle of quite high regional inflation rate. However, by encouraging agriculture and labor-intensive industries, it can increase people's purchasing power. Although it may not stimulate economic growth too high, at least it can significantly impact the well-being of lower middle class people. Capital expenditure of local government has a rather important role in economic growth. The increase of economic activity that later will lead to economic growth is inseparable from the role of local government to provide public services. This facility may be run by local government through capital expenditures in each district/city in the region. To further enhance each region's economic growth, it is necessary to supervise and control the use of the fund for development so that it is right on target. Capital Expenditure should be of particular concern for local government because it is closely related to public facilities, since with the facility, economic activity will be able to run more smoothly so that economic growth can be improved.

Suppresing inflation rate in Banten Province. Economic growth is also affected by inflation rate. Controling inflation in the region must be the commitment of local government in maintaining the level of people's consumption, which is the large source of regional economic growth. Controlling process is a cooperation among local government so that it can give positive signal to regional economy. The continuation of inflation in various regions indirectly affects national inflation rate, therefore, the role of Regional Inflation Controlling Team (TPID) is much needed to control regional inflation rate so that it will not soar. The number of inflation in Banten Province in 2015 is up to 9.65 percent. If local government actively involves and coordinats with central government as well as reports several things related to inflation such as weather condition, harvesting condition, and harvesting distribution, and if inflation in the region is contained, then central government will be at ease to pursue economic growth. In addition to control inflation in the region, there are 3 (three) important things that become mandatory agenda of local government, namely to maintain economic 
stability by decreasing the ongoing transaction deficit, maintaining economic growth by decreasing the poverty rate and unemployment, as well as maintaining the growth of people's consumption.

According to informants in the field, the regional economic potential development method in Banten Province could be conducted by: (a) Developing agriculture productivity and variety in a broad sense (farming, forestry, husbandry, and agriculture): maintenance and development as well as optimizing the use of agriculture infrastructure facilities, surveillance of production facilities distribution and anticipation of pests and environmental damage, development of agriculture human resources and empowerment of instructors, increasing the productivity of land and the variety of plantation, husbandry, and fishery, development of seeding, strengthening of research and development and the use of more profitable technology for farmers, development of forest management with people, optimizing people's lands for plants development and livetock farming and as well as in land/freshwater fishery to meet family nutrition and business, (b) Developing the processing and marketing of agriculture products in a broad sense: development of home industry for agriculture products manufacturing with varied growth in villages through processed quality improvement, processed creation, packaging, promotion and marketing, capital assistance or loan, restructuring the management of Sragi sugar factory, market development and agriculture products marketing cooperation development, and (c) Developing the Productivity and Business of Batik, Convection, small and medium textile: development of regional conducive climate for the growth of Batik and textile business, development of promotion for the use of local products, improvement of cooperation network information in the field od industry and tradem development of partnership in assisting marketing and material management, preservation and development of economic potential of Batik and local textile, and development of local product competitiveness.

\section{CONCLUSION}

Attraction of foreign and domestic investors to invest their capital in Banten Province is still low, although in reality there are economic potential and economic structure in the region. The influence of economic condition in Banten Province region (regional economic potential and economic structure) towards investors' attraction is economic potential (people's purchasing power and economic growth) is not fully developed by local government, and regional economic structure (primary, secondary, and tertiary) is not really supporting, so that investors are not really interested in investing their capital in Banten Province. Therefore, it is suggested that more appropriate strengthening regional economic policy is still needed to improve the investment attraction in Banten Province, specifically to increase people's purchasing power to support domestic consumption, to increase Regional GRDP of district/cities with low Regional GRDP, to increase Regional GRDP of district/cities in which the business sector is still low/small in contribution if compared to other sectors, and to maintain the relatively low Construction Cost Index (CCI).

\section{REFERENCES}

Agussalim,. (2011). Otonomi Daerah dan Pengembangan Investasi: Modul pada Diklat Subtantif Perencanaan Investasi Daerah. Makassar: BAPPENAS-PSKMP UNHAS.

Astuti, T. (2009). Analisis Faktor Daya Tarik Investasi dan Persepsi Dunia Usaha di Kota Batam (Master Thesis). Universitas Gadjah Mada.

Bappeda Aceh Utara,. (2010). Peranan Pemetaan Potensi Ekonomi Daerah dalam Mendukung Pembangunan Daerah Kabupaten Aceh Utara. Aceh Utara: Bappeda Aceh Utara.

Bappenas,. (2012). Perekonomian Indonesia Tahun 2012: Prospek dan Kebijakan.

Creswell, J. (2014). Research Design: Qualitative, Quantitative, and Mixed Methods Approaches (4th ed.). Thousand Oaks, California: SAGE Publications.

Dumairy,. (2004). Perekonomian Indonesia. Jakarta: Erlangga.

Fahmi, I. (2006). Analisis Investasi dalam Perspektif Ekonomi dan Politik. Bandung: Refika Aditama.

Husna, N., Noor, I., \& Rozikin, M. (2012). Analisis Pengembangan Potensi Ekonomi Lokal untuk Menguatkan Daya Saing Daerah di Kabupaten Gresik. Jurnal Administrasi Publik (JAP), 1(1).

Jones, C. (2004). Investments: Analysis and Management. New York: Business Wire.

KPPOD,. (2005). Daya Saing Investasi Kabupaten/ Kota di Indonesia Tahun 2005: Persepsi Dunia Usaha (Peringkat 169 Kabupaten dan 59 Kota di Indonesia: Metodologi dan Temuan Utama). Jakarta: KPPOD.

Masri, A. (2009). Faktor-faktor Penentu Daya Tarik Investasi Kabupaten Padang Pariaman (Master Thesis). Universitas Indonesia.

Minardi, A. (2014). Daya Saing Investasi di Daerah. Investor Daily Indonesia.

Nurdiyanto, E. (2013). Struktur Ekonomi dan Proyeksi Penyerapan Tenaga Kerja Sektoral di Indonesia Tahun 2011-2012. Bandung: Tarsito.

Republik Indonesia,. (2007). Undang-undang Republik Indonesia Nomor 25 Tahun 2007 tentang Penanaman Modal. Jakarta: Sekretariat Negara. 
Republik Indonesia,. (2008). Peraturan Pemerintah Republik Indonesia Nomor 45 tahun 2008 tentang Pedoman Pemberian Insentif dan Pemberian Kemudahan Penanaman Modal di Daerah. Jakarta: Sekretariat Negara.

Sugiarto, E. (2015). Investasi Dan Pembangunan Ekonomi. Setkab.go.id, from http://setkab. go.id/investasi-dan-pembangunan-ekonomi/

Sujatmiko, D. (2012). Analisis Investasi di Kota Yogyakarta, 2007 - 2011 (Master Thesis). Universitas Gadjah Mada.

Sunariyah,. (2004). Pasar Modal dan Investasi. Jakarta: Salemba Empat.

Tandelilin, E. (2010). Portofolio dan Investasi.
Yogyakarta: Kanisius.

Whitney, F. \& Milholland, J. (1933). A Four-Year Continuation Study of a Teachers College Class. The Journal of Educational Research, 27(3), 193-199. http://dx.doi.org/10.1080/0022067 1.1933 .10880392

Wibowo, R. (2011). Strategi Pengembangan Investasi Daerah di Kabupaten Wonosobo (Undergraduate Thesis). Universitas Negeri Semarang.

Yin, R. (2014). Case Study Research: Design and Methods (Applied Social Research Methods) (5th ed.). Thousand Oaks, California: SAGE Publications. 